\title{
СИСТЕМИ КОМП'ЮТЕРНОЇ МАТЕМАТИКИ ЯК ЗАСІБ ФОРМУВАННЯ МАТЕМАТИЧНОÏ КОМПЕТЕНТНОСТІ СТУДЕНТІВ У ПРОЦЕСІ НАВЧАННЯ ВИЩОЇ МАТЕМАТИКИ
}

\section{О. С. Грицюк}

Кременчуцький національний університет імені Михайла Остроградського

вул. Першотравнева, 20, 39600, м. Кременчук, Україна. E-mail: myboxua13@ gmail.com

Проаналізовано методологічні й організаційні аспекти математичної підготовки студентів з використанням систем комп'ютерної математики. Розроблено систему розв'язання лінійних рівнянь засобами комп'ютерної математики, яка містить різні способи розв'язання систем лінійних рівнянь, на підставі програмного комплексу «MATLAB». Завданням даної системи $€$ формування математичної компетентності студентів у процесі навчання вищої математики. Розглянуто основні переваги використання комп'ютерної математики у математичній підготовці, зокрема: наявність потужних інтерактивних довідкових матеріалів; інтерактивне розв'язання математичних задач за допомогою комп'ютера, завдяки чому забезпечується поетапне (покрокове) контрольоване навчання новим методам розв'язання; негайна реакція комп'ютера на хибний крок, що дозволяє відразу ж поправити студента. Визначено цілі використання засобів інформаційно-комунікаційних технологій та комп'ютерної математики на заняттях з вищої математики, а саме: розвиток міжпредметних зв'язків математики та інформатики; формування математичної компетентності та комп’ютерної грамотності. Зазначено, що: використання систем комп'ютерної математики прискорює темп навчання, вивільняє час, отже, інтенсифікує процес навчання; дозволяє сформувати математичну компетентність завдяки розвитку просторового, алгоритмічного, інтуїтивного, творчого, теоретичного мислення студентів. Для формування математичної компетентності студентів у процесі навчання вищої математики запропоновано розв'язування системи лінійних рівнянь за допомогою MATLAB одним з двох наочних способів: графічним або за допомогою спеціальної функції.

Ключові слова: інформаційно-комунікаційні технології, комп'ютерна математика, програмні засоби IКТ, MATLAB, математична компетентність, математична підготовка, вища математика.

\section{СИСТЕМЫ КОМПЬЮТЕРНОЙ МАТЕМАТИКИ КАК СРЕДСТВО ФОРМИРОВАНИЯ МАТЕМАТИЧЕСКОЙ КОМПЕТЕНТНОСТИ СТУДЕНТОВ В ПРОЦЕССЕ ОБУЧЕНИЯ ВЫСШЕЙ МАТЕМАТИКЕ}

\section{Е. С. Грицюк}

Кременчугский национальный университет имени Михаила Остроградского

ул. Первомайская, 20, 39600, г. Кременчуг, Украина. E-mail: myboxua13@gmail.com

Проанализированы методологические и организационные аспекты математической подготовки студентов с использованием систем компьютерной математики. Разработана система решения линейных уравнений средствами компьютерной математики, которая включает в себя различные способы решения систем линейных уравнений на основе программного комплекса «MATLAB». Задачей данной системы является формирование математической компетентности студентов в процессе обучения высшей математике. Рассмотрены основные преимущества использования компьютерной математики для математической подготовки, в частности: наличие мощных интерактивных справочных материалов; интерактивное решение математических задач с помощью компьютера, благодаря чему обеспечивается поэтапное (пошаговое) контролируемое обучение новым методам решения; немедленная реакция компьютера на ошибочный шаг позволяет тут же поправить студента. Определены следующие цели использования средств информационно-коммуникационных технологий и компьютерной математики на занятиях по высшей математике: развитие межпредметных связей математики и информатики; формирование математической компетентности и компьютерной грамотности. Отмечено, что: использование систем компьютерной математики ускоряет темп обучения, высвобождает время и, следовательно, интенсифицирует процесс обучения; позволяет сформировать математическую компетентность благодаря развитию пространственного, алгоритмического, интуитивного, творческого, теоретического мышления студентов. Для формирования математической компетентности студентов в процессе обучения высшей математике предложено решение системы линейных уравнений с помощью MATLAB одним из двух наглядных способов: графическим или с помощью специальной функции.

Ключевые слова: информационно-коммуникационные технологии, компьютерная математика, программные средства ИКТ, MATLAB, математическая компетентность, математическая подготовка, высшая математика.

АКТУАЛЬНІСТЬ РОБОТИ. Сучасна освіта переживає складний етап докорінної перебудови під впливом інформатизації. Зміни торкаються усіх сфер і складових освіти: змісту навчання, його форм, методик, технологій, ролі і міста викладача, який сьогодні має не лише транслювати певний комплекс наукової інформації, а й організовувати навчальний процес 3 метою набуття студентами загальнонаукових і фахових компетенцій.

Системне, ефективне формування інформаційної та математичної компетенцій, передбачених програмами 3 навчальної дисципліни «Вища математика», для основної маси викладачів і студентів сьогодні можливо лише за умови використання інформаційно-комунікативних технологій (ІКТ). 
Інформаційно-комунікаційні технології О. Спірін визначає як технології розробки інформаційних систем і побудови комунікаційних мереж, що, зазвичай, передбачає психолого-педагогічний супровід процесів проектування, розроблення, упровадження та підтримки, а також технології використання таких систем і мереж для формалізації і розв'язування задач у будь-яких предметних галузях [1].

Отже, інформаційно-комунікаційні технології розуміємо як сукупність сучасної комп'ютерної техніки, засобів телекомунікаційного зв'язку, інструментальних програмних засобів, що забезпечують інтерактивний програмно-методичний супровід інноваційних педагогічних технологій.

ІКТ $є$ істотним засобом інформатизації, оскільки їх своєчасне та коректне використання усіма фахівцями, які працюють в системі освіти, є запорукою ефективної підготовки студентів.

Під педагогічними технологіями $з$ використанням засобів ІКТ розуміється комплекс методів, прийомів та засобів, які сприяють створенню педагогічних умов для оптимізації діяльності викладача зі збору, адаптації, моделювання та передачі інформації, забезпечення контролю за навчальним процесом на основі використання комп'ютерної техніки, засобів телекомунікаційного зв'язку та інтерактивного програмного продукту.

У попередніх дослідженнях [2] було зазначено, що формування математичної компетентності неможливе без набуття фундаментальних математичних знань, опанування методів математичного моделювання та комп'ютерної математики, необхідних для розв'язання професійно орієнтованих задач.

Важливою складовою сучасних ІКТ навчання вищої математики є такі, що базуються на застосуванні систем комп'ютерної математики (СКМ) [3]. Під СКМ Т. Кобильник і У. Когут розуміють поліфункціональні, універсальні програмні засоби, призначенні для ефективного виконання математичних операцій з даними як у символьній, так і в числовій формі, візуалізації математичних закономірностей, проведення навчальних i наукових досліджень, а також моделювання процесів і явищ у різних предметних галузях. На думку дослідників, СКМ виокремлені в окрему групу завдяки тому, що є більш універсальними й об'єднують функції засобів інших типів, наприклад другого і третього, на противагу першому типу, що має більш обмежене застосування [4].

Пропонуємо наступне визначення СКМ. Системи комп'ютерної математики є складним, багаторівневим комплексом програмного забезпечення, який використовується з метою чисельних розрахунків за допомогою комп'ютерної техніки, а також для трансформації об'єктів математики і графіки у аналітичні чи символьні.

Зараз СКМ широко використовують для розв'язання наукових, інженерних, навчальних задач, наочної візуалізації даних і результатів обчислень та як зручні й повні довідники з математичних обчислень. Використання СКМ дає змогу значною мірою підсилити інтелектуальну діяльність, дозволяє автоматизувати виконання не тільки чисельних, а й аналітичних (символьних) обчислень та графіч- них побудов [5]. Разом 3 тим, застосування СКМ тими, хто не має достатніх знань, умінь і навичок розв'язувати математичні задачі, може привести до некоректних результатів [6].

Мета статті полягає у дослідженні систем комп'ютерної математики як засобу формування математичної компетентності студентів у процесі навчання вищої математики.

Для розв'язання поставлених завдань використано методи: теоретичний - для вивчення й аналізу науково-педагогічної літератури, навчальних програм, посібників, узагальнення інформації для визначення теоретико-методологічних основ дослідження; метод опису інтерактивних форм навчання із застосуванням засобів СКМ; аналітичний - аналіз особливостей розв'язання систем рівнянь за допомогою системи MATLAB.

МАТЕРІАЛ І РЕЗУЛЬТАТИ ДОСЛІДЖЕНЬ. Необхідність використання ІКТ, зокрема систем комп'ютерної математики (СКМ), у навчанні вищої математики у закладах вищої освіти вивчалася у роботах низки дослідників, у тому числі зарубіжних вчених.

Зокрема, організацію навчального процесу в комп'ютерно орієнтованому навчальному середовищі досліджували Т. Поясок і О. Беспарточна [7], M. І. Жалдак, В. В. Лапінський і М. І. Шут [8]. Питанням ефективності використання засобів ІКТ в освіті займалися В. Биков і М. Лещенко [9], Н. Морзе і О. Буйницька [10]. Різні можливості засобів ІКТ у навчанні вищої математики розглядали M. І. Жалдак [11], Н. Кіяновська, Н. Рашевська і С. Семеріков [12]. Водночас низку проблем, пов'язаних 3 використанням СКМ як відповідних програмних засобів ІКТ для ефективного формування математичної компетентності студентів, вивчали Н. Д. Парфьонова [13], C. I. Почтовюк [14], Ю. І. Сінько [15], В. Ертель [16], Х. Барендрегт і Ф. Відійк [17], Д. А. Покришень і Є. Ю. Носенко [18], застосуванню системи MATLAB для удосконалення математичної підготовки були присвячені праці К. Молера [19], С. Отто і Ж. Денієра [20], М. Абдула Махіда [21].

Однією з основних проблем у вивченні навчальних дисциплін «Вища математика» і «Алгебра та геометрія» у закладах вищої освіти коректне відтворення математичних об'єктів, зумовлена тим, що зображення навіть елементарних математичних формул або систем рівнянь, виконані в зошитах або на дошці, часто містять похибки. Сучасні комп'ютерні засоби дозволяють вирішити цю проблему. Алгебра - це один $з$ небагатьох підрозділів вищої математики, для якого не потрібно агітувати щодо використання засобів комп'ютерної математики. Сучасні СКМ дозволяють створювати графіки складних функцій і їх комбінацій, обертати їх на екрані.

Тому система розв'язання математичних задач засобами СКМ покликана допомогти викладачу вищої математики успішніше впоратися 3 розв'язанням поставлених перед ним завдань, а іï використання у процесі навчання вищої математики підвищить доступність складного навчального матеріалу для ширшого кола студентів. 
На заняттях з навчальної дисципліни «Алгебра та геометрія» використання засобів комп'ютерної математики докладно ілюструє побудову графіків елементарних та складних функцій і перетворення графіків.

Отже, комп'ютер використовується переважно для посилення наочності. Це активізує пізнавальний процес студентів, розвиває мислення (наочно-дієве, наочно-образне), прискорює засвоєння знань і вмінь, а отже, формування загальних та фахових компетенцій.

Цілі використання можливостей засобів ІКТ та комп'ютерної математики на заняттях з вищої математики передбачають:

- посилення міжпредметних зв'язків математики та інформатики;

- формування математичної компетентності та комп'ютерної грамотності;

- розвиток навичок самостійної роботи студентів на занятті;

- підвищення пізнавальної активності студентів.

Задачі викладачів інформатики і математики наступні:

- забезпечити фундаментальну математичну підготовку студентів;

- формувати у студентів інформаційну культуру, творчий стиль діяльності;

- підготувати і використовувати під час занять навчальні засоби ІКТ та комп’ютерної математики.

Найголовніше, що вигідно відрізняє СКМ від інших програмних засобів IКТ - це інтерактивне розв'язання математичних задач за допомогою комп'ютера, завдяки чому забезпечується поетапний (покроковий) контроль за роботою студента. Це знімає одразу дві проблеми:

- програма покроково перевіряє студента, вказуючи на його поточні помилки і підказуючи вихід 3 важкої ситуації;

- негайна реакція комп'ютера на хибний крок дозволяє відразу ж поправити студента, уникнути мимовільного запам'ятовування помилкових ходів.
Саме в цьому полягає незаперечна перевага використання можливостей засобів СКМ у вивченні вищої математики: викладач отримує індивідуального помічника - безпосереднього наставника персонально для кожного студента.

У більшості засобів комп'ютерної математики передбачені потужні інтерактивні довідкові матеріали, великі за обсягом, тому по закінченні розв'язання СКМ видає чіткі рекомендації щодо подальшої роботи над завданням і навіть відкриває в електронній довідці той матеріал, який необхідно додатково опрацювати.

Таке покрокове контрольоване рішення відповідає важливому педагогічному принципу: не перевіряти наявні знання, а навчати новим методам розв'язання.

Розглянемо процес формування математичної компетентності студентів на заняттях 3 навчальної дисципліни «Вища математика» під час розв'язання математичних задач засобами CKM «MATLAB» за темою «Системи лінійних рівнянь».

Серед можливостей системи MATLAB Т. Кобильник і У. Когут визначають такі: а) розв'язування різноманітних задач математичного аналізу (обчислення границь; диференціювання й інтегрування функцій як аналітично, так і чисельно; перетворення Фур'є тощо); б) реалізація алгоритмів обчислювальної математики (сплайн-інтерполяція, метод РунгеКутта для розв'язування звичайних диференціальних рівнянь тощо); в) розв'язування задач умовної i безумовної оптимізації (зокрема задач лінійного, дискретного та нелінійного програмування); г) розв'язування задач лінійної алгебри (додавання, множення, обчислення оберненої, транспонованої матриць, обчислення визначників і мінорів, множення матриці на вектор, пошук власних значень i векторів, розв'язування матричних рівнянь тощо) [4].

Користувацький інтерфейс системи MATLAB багатовіконний та має ряд засобів прямого доступу до різних компонентів системи (рис. 1).

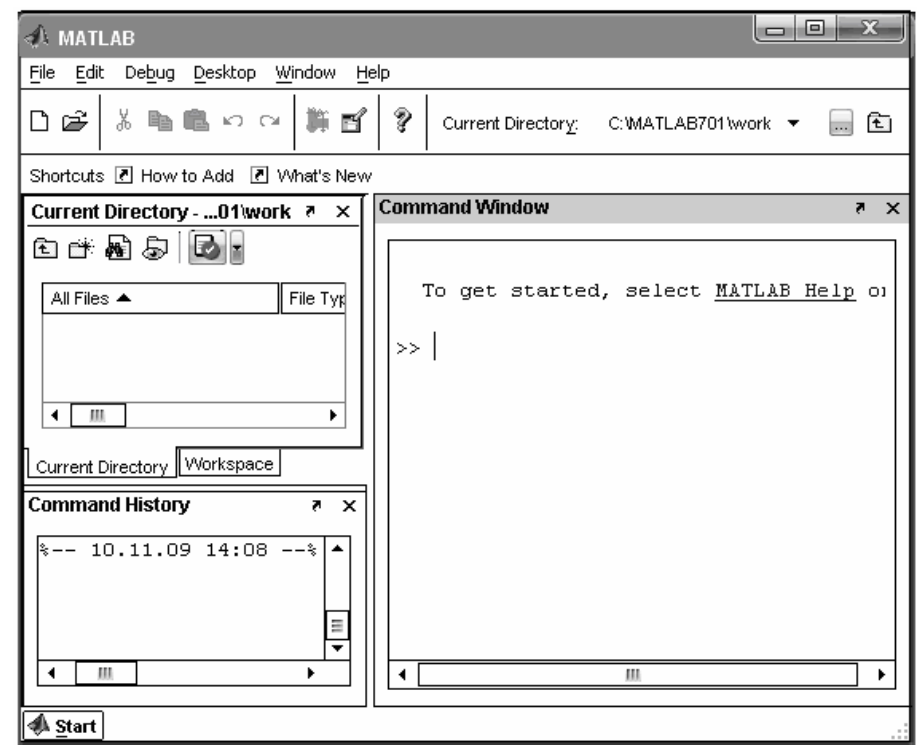

Рисунок 1 - Інтерфейс системи MATLAB 
Основну частину вікна займає командне вікно прикладної програми (Command Window), в якому розташований рядок введення, що починається спеціальним маркером - символами «〉>». В ньому записуються команди для виконання системою. У лівій частині вікна прикладної програми розташоване вікно історії команд (Command History), в якому відображаються введені користувачем команди. За необхідності ці команди можна виконувати, зробивши подвійне натискання мишею на потрібній команді у вікні історії команд.

Введення команди завершується натисканням клавіші [Enter], водночас MATLAB одразу ж виконує команду і виводить у наступному рядку результат. Для того, щоб результат не виводився на екран, наприкінці команди ставиться символ «;».

Якщо команда занадто довга, то можна перенести частину іiі на новий рядок. Для цього в місці перенесення треба поставити пробіл і три крапки (...), а потім з нового рядка продовжити запис команди.

Для очищення командного вікна використовується команда сlс.

Центральним поняттям усіх математичних систем є математичний вираз. Він задає те, що має бути обчислено у чисельному (іноді символьному) вигляді. Математичні вирази будуються на основі чисел, констант, змінних, операторів, функцій та різних спецзнаків [22].

Число - найпростіший об'єкт мови MATLAB, який представляє кількісні дані. Числа використовуються в загальноприйнятому уявленні про них. Вони можуть бути цілими, дробовими, з фіксованою і плаваючою комою, комплексні. Приклади представлення чисел в MATLAB наведено в табл. 1.

Таблиця 1 - Приклади подання чисел

\begin{tabular}{|c|c|}
\hline Звичайне виведення & У системі MATLAB \\
\hline 2 & 2 \\
\hline$-3,4$ & -3.4 \\
\hline$-123,241$ & $-1.23241 \mathrm{e} 2$ \\
\hline 0,000412 & $4.12 \mathrm{e}-4$ \\
\hline $2+3,7 \mathrm{i}$ & $2+3.7 \mathrm{i}$ \\
\hline 0,54 & .54 \\
\hline $0,2+3 \mathrm{i}$ & $.2+3 \mathrm{i}$ \\
\hline
\end{tabular}

Константа - це завчасно визначене числове чи символьне значення, подане унікальним ім'ям [22]. B MATLAB існують деякі стандартні константи, наприклад число «пі» (pi), значення уявної одиниці (i). Символьною сталою вважається будь-яка послідовність символів, укладених в апострофи, наприклад 'Hello!'.

Змінні - це іменовані об'єкти для зберігання числових, символьних, векторних чи матричних даних [22].

Ім'я змінної повинне починатися 3 літери, може містити букви, цифри і символ підкреслення. Ім'я не повинно збігатися з іменами інших змінних, функцій і процедур системи. Прописні і рядкові букви в MATLAB розрізняються. Отже, змінні s i $\mathbf{S}$ - це дві різні змінні.
Розв'язання систем лінійних рівнянь належить до самої масової області застосування матричних методів. Як відомо, звичайна система лінійних рівнянь має вигляд:

$$
\left\{\begin{array}{c}
a_{1} 1 x 1+a_{1} 2 \times 2+\ldots+a_{1} n \times n=b_{1} \\
a_{2} 1 x 1+a_{2} 2 x 2+\ldots+a_{2} n x n=b_{2} \\
\ldots \ldots \ldots . . \\
a_{n} 1 x 1+a_{n} 2 \times 2+\ldots+a_{n} n x n=b_{n}
\end{array} .\right.
$$

Розглянемо різні способи розв'язування систем лінійних рівнянь у MATLAB, що можуть бути запропоновані студентам першого курсу.

Для формування математичної компетентності студентів у процесі навчання вищої математики пропонується розв'язувати систему лінійних рівнянь за допомогою MATLAB одним 3 двох наочних способів.

1) Розв'язання систем рівнянь графічним способом.

Якщо система (лінійних або нелінійних) рівнянь містить два рівняння і вони являють собою нескладні вирази, то можна розв'язати систему рівнянь графічним способом. Для цього потрібно:

1. Висловити одне з невідомих системи рівнянь через інше в кожному із рівнянь.

2. Задати діапазон значень аргументу отриманих функцій.

3. Задати функції.

4. Побудувати графіки функцій.

5. Додати лінії сітки.

6. Знайти точку перетину графіків функцій. Її координати - розв'язання системи рівнянь (абсциса значення невідомого, через яке було виражено інше невідоме, ордината - значення вираженого невідомого). За необхідності масштабувати графік.

Приклад.

Розв'язати систему рівнянь

$$
\left\{\begin{array}{c}
2 \cdot x_{1}-x_{2}=4 \\
5 \cdot x_{1}+2 \cdot x_{2}=3
\end{array}\right.
$$

Виразимо друге невідоме системи рівнянь через перше, отримаємо

$$
\left\{\begin{array}{c}
x_{2}=2 \cdot x_{1}-4 \\
x_{2}=1,5-2,5 \cdot x_{1} .
\end{array} .\right.
$$

Нехай перша функція $Y 1=2 X-4$, друга функція $Y 2=1,5-2,5 X$.

Порядок вводу:

$>\mathrm{X}=-2: 0.5: 2$;

$>\mathrm{Y}_{1}=2 * \mathrm{X}-4$

$\gg \mathrm{Y}_{2}=1.5-2.5^{*} \mathrm{X}$

$>\operatorname{plot}(\mathrm{X}, \mathrm{Y} 1, \mathrm{X}, \mathrm{Y} 2)$

$>$ grid

У результаті отримаємо графік, поданий на рис. 2, масштабуючи який, можна побачити, що $x_{1}=1,222, x_{2}=-1,556$. 


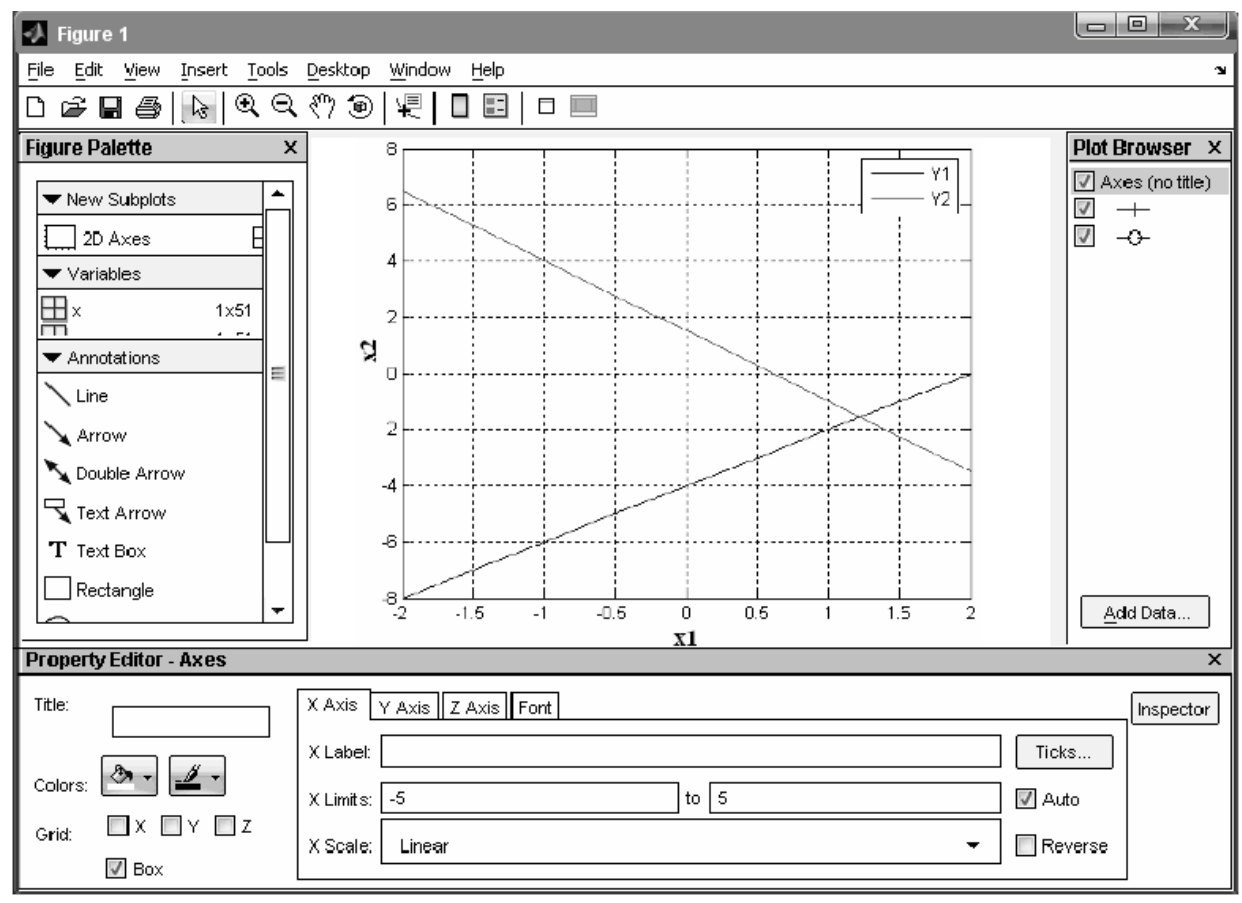

Рисунок 2 - Графічне розв’язання системи лінійних рівнянь у СКМ «MATLAB»

\section{2) Розв'язання систем рівнянь за допомогою} функції solve.

Для розв'язання систем лінійних чи нелінійних рівнянь в MATLAB існує спеціальна функція solve. Щоб розв'язати систему рівнянь за допомогою цієї функції, потрібно:

1. Визначити символьні змінні (невідомі системи рівнянь).

2. Обчислити невідомі за формулою

$[\mathrm{x} 1, \mathrm{x} 2, \ldots]=$ solve ('рівняння 1','рівняння2',...).

3. Вивести знайдене рішення із заданою точністю, використовуючи функцію vра(змінна, число знаків).

Приклад

Розв'язати систему рівнянь

Порядок вводу:

$$
\left\{\begin{array}{c}
2 \cdot x_{1}-x_{2}=4 \\
5 \cdot x_{1}+2 \cdot x_{2}=3
\end{array}\right.
$$

$>$ syms x1 x2

$>>[\mathrm{x} 1, \mathrm{x} 2]=\operatorname{solve}\left({ }^{\prime} 2 * \mathrm{x} 1-\mathrm{x} 2=4{ }^{\prime},{ }^{\prime} 5 * \mathrm{x} 1+2 * \mathrm{x} 2=3\right.$ ');

$>\operatorname{vpa}(\mathrm{x} 1,4)$

$>\operatorname{vpa}(\mathrm{x} 2,4)$

У результаті отримаємо $x 1=1,222, x 2=-1,556$.

Використання IКТ сприяє розвиткові різних типів мислення, зокрема просторового, алгоритмічного, інтуїтивного, творчого, теоретичного. Інтерактивність $\epsilon$ умовою формування уміння швидко обирати оптимальний варіант розв'язання задачі. ІКТ виводять на новий рівень експериментальнодослідницьку діяльність студентів (передусім, завдяки зміні шляхів і методів обробки інформації та можливостям комп'ютерного моделювання та). Варто також підкреслити один з головних ефектів IКТ у навчанні, а саме формування загальної інформаційної культури. Усе вищезазначене прискорює темп навчання, вивільняє час, отже, інтенсифікує процес навчання.
ВИСНОВКИ. Отже, мета використання засобів інформаційно-комунікаційних технологій та комп'ютерної математики у процесі математичної підготовки полягає у формуванні математичної компетентності та комп’ютерної грамотності студентів та передбачає розвиток міжпредметних зв'язків математики та інформатики.

Використання систем комп'ютерної математики як найефективніших засобів IКТ на заняттях 3 навчальних дисциплін «Вища математика» $\mathrm{i}$ «Алгебра та геометрія» підвищує рівень засвоєння математичних знань, дає змогу викладачеві значно зекономити час за рахунок контролю і перевірки знань у інтерактивному режимі, що $є$ надзвичайно актуальним в умовах скорочення обсягу аудиторних занять, i, насамкінець, сприяє формуванню математичної компетентності студентів.

Основними перевагами використання СКМ у математичній підготовці $є$ залучення до навчального процесу додаткового комплексу інтерактивних довідкових матеріалів; формування вмінь інтерактивного розв'язання математичних задач засобами IКТ.

Перспективи подальших досліджень вбачаємо у аналізі ефективності впровадження систем комп'ютерної математики у підготовку студентів інженерно-технічних спеціальностей та обгрунтуванні методології навчання математичних дисциплін засобами СКМ.

\section{ЛІТЕРАТУРА}

1. Спірін О. М. Інформаційно-комунікаційні та інформатичні компетентності як компоненти системи професійно-спеціалізованих компетентностей вчителя інформатики. Інформаційні технології $i$ засоби навчання. 2009 . Т. 13, № 5. URL: https://journal.iitta.gov.ua/index.php/itlt/article/view/18 3/169 (дата звернення: 03.02.2019). 
2. Грицюк О. С., Беспарточна О. І. Структура математичної підготовки студентів інженерних спеціальностей в аспекті професійної спрямованості навчання. Педагогіка формування творчої особистості у вищій $i$ загальноосвітній школах. 2016. № 51 (104). С. 436-443.

3. Михалевич В. М., Тютюнник О. І. Проектування навчальних задач з лінійного програмування з використанням систем комп'ютерної математики. Інформаційні технології $i$ засоби навчання. 2013. T. 38, № 6. C. 123-137.

4. Кобильник Т. П., Когут У. П. Системи комп'ютерної математики у навчанні студентів напряму підготовки «Інформатика». Інформаційні технології $i$ засоби навчання. 2014. Т. 40, № 2. С. 5064.

5. Парфьонова Н. Д., Клочко Т. В. Обчислення інтегралів від функцій комплексної змінної за допомогою залишків в системах комп'ютерної математики. Інформаційні технології $i$ засоби навчання. 2009. T. 14, № 6. URL: https://journal.iitta.gov.ua/ index.php/itlt/article/view/211/197 (дата звернення: 05.02.2019).

6. Кобильник Т. П. Програмне забезпечення спеціального призначення у навчанні студентів інформатичних спеціальностей педагогічного університету. Інформаційні технології $i$ засоби навчання. 2011. T. 23, № 3. URL: https://journal.iitta.gov.ua /index.php/itlt/article/view/440/410 (дата звернення: 05.02.2019).

7. Поясок Т. Б., Беспарточна О. І. Організація педагогічної взаємодії учасників освітнього процесу в комп'ютерно орієнтованому навчальному середовищі закладу вищої освіти. Інформаційні технологіi $i$ засоби навчання. 2018. Т. 67, № 5. С. 199-212.

8. Жалдак М. І., Лапінський В. В., Шут М. І. Комп'ютерно-орієнтовані засоби навчання математики, фізики, інформатики: Посібник для вчителів. К.: НПУ імені М.П. Драгоманова, 2004. 182 с.

9. Биков В. Ю., Лещенко М. П. Цифрова гуманістична педагогіка: актуальні проблеми педагогічних досліджень у галузі використання ІКТ в освіті. Інформаційні технологї $i$ засоби навчання. 2016. T. 53, № 3. C. 1-17.

10. Морзе Н. В., Буйницька О. П. Підвищення рівня інформаційно-комунікаційної компетентності науково-педагогічних працівників - ключова вимога якості освітнього процесу. Інформаційні технології $i$ засоби навчання. 2017. Т. 59, № 3. С. 189-200.

11. Жалдак М. І. Комп'ютер на уроках математики: Посібник для вчителів. К.: Дініт, 2003. 324 с.
12. Кіяновська Н. М., Рашевська Н. В., Семеріков С. О. Етапи розвитку теорії і методики використання інформаційно-комунікаційних технологій у навчанні вищої математики студентів інженерних спеціальностей у Сполучених Штатах Америки. Iнформаційні технології $i$ засоби навчання. 2014. T. 43, № 5. C. 68-83.

13. Парфьонова Н. Д. Нові підходи до використання вільно поширюваної системи комп'ютерної математики Maxima у навчанні функцій комплексної змінної. Інформаційні технології $i$ засоби навчання. 2012. T. 27, № $1 . \quad$ URL: https://journal.iitta.gov.ua/index.php/itlt/article/view/62 2/481 (дата звернення: 07.02.2019).

14. Почтовюк C.I. MATLAB - математична комп'ютерна система для науково-дослідницьких та технічних розрахунків. Інформаційні технології $i$ засоби навчання. 2009. Т. 9, № 1. URL: https://journal.iitta.gov.ua/index.php/itlt/article/view/18/ 10 (дата звернення: 10.02.2019).

15. Сінько Ю. І. Системи комп“ютерної математики та їх роль у математичній освіті. Інформаційні технології в освіті. 2009. № 3. С. 274-278.

16. Ertel W. Advanced Mathematics for Engineers. Weingarten: University of Applied Sciences Ravensburg-Weingarten, 2012. 224 p.

17. Barendregt H., Wiedijk F. The Challenge of Computer Mathematics. Philosophical transactions. Series A, Mathematical, Physical, and Engineering Sciences. 2005. No. 363 (1835). P. 2351-2373.

18. Покришень Д. А., Носенко С. Ю. ІКТ для розв'язування системи нерівностей. Інформаційні технології $і$ засоби навчання. 2012. T. 27, № 1. URL: https://journal.iitta.gov.ua/index.php/itlt/article/view/61 3/472 (дата звернення: 07.02.2019).

19. Moler C. B. Numerical Computing with MATLAB. Philadelphia, PA: SIAM, 2004. 336 p.

20. Otto S. R., Denier J. P. An Introduction to Programming and Numerical Methods in MATLAB. London: Springer-Verlag London Limited, 2005. 463 p.

21. Abdul Majid M., Huneiti Z. A., Balachandran W., Balarabe Y. Matlab as a Teaching and Learning Tool for Mathematics: A Literature Review. International Journal of Arts \& Sciences. 2013. No. 6 (3). P. 23-44.

22. Шаповаленко В. А., Буката Л. М., Трофименко О. Г. Чисельні методи моделювання об'єктів: Частина 2: Метод. вказівки для лаб. та практ. занять. Модуль 2. Одеса: ВЦ ОНАЗ, 2011. 72 с.

\section{COMPUTER MATHEMATICS SYSTEMS AS TOOLS OF STUDENTS' MATHEMATICAL COMPETENCE FORMATION IN LEARNING MATHEMATICS O. Hrytsiuk}

Kremenchuk Mykhailo Ostrohradskyi National University

vul. Pershotravneva, 20, 39600, Kremenchuk, Ukraine. E-mail: myboxua13@gmail.com

Purpose. The paper analyzes methodological and organizational aspects of students' mathematical education using computer mathematics systems. Methodology. The research was conducted using systematic and interdisciplinary approaches, with the help of general scientific methods: analysis, synthesis, comparison, induction and deduction, as well as descriptive method. Findings. The system of linear equations solving by computer mathematics tools, which contains different ways of solving systems of linear equations based on the MATLAB application, are developed. The task of this system is students' mathematical competence formation in the process of learning mathematics. The main bene- 
fits of the use of computer mathematics in mathematics learning have been analyzed, in particular: the presence of powerful interactive help information; interactive solution of mathematical tasks using a computer, thereby providing a phased (step by step) controlled learning new methods of solution; immediate computer response to the wrong step allows immediately correct the student. The purposes of use tools of information and communication technologies and computer mathematics on mathematics lessons namely are set forth, in particular: development of integrative connections between mathematics and computer science; mathematical competence and computer skills formation. Originality. The scientific novelty consists in the fact that the use of computer mathematics increases learning rate, frees up time, therefore, intensifies the process of learning; allows to develop the mathematical competence through the formation of spatial, algorithmic, intuitive, creative, and theoretical thinking in students. Practical value. The use of systems of computer mathematics as the most effective means of ICT in classes on «Higher Mathematics» and «Algebra and geometry» increases the level of mastering of thematic knowledge, allows the teacher to save considerable time by controlling and checking knowledge in interactive mode, which is extremely relevant in the context of reducing the volume of classroom activities, and, finally, contributes to the formation of mathematical competence of students. Conclusions. For students' mathematical competence formation in the process of learning mathematics proposed solution of linear equations using MATLAB one of two visual ways: graphic method or using a special function.

Key words: information and communication technologies, computer mathematics, ICT software, MATLAB, mathematical competence, mathematics education, mathematics.

\section{REFERENCES}

1. Spirin, O. M. (2009), "Informatsiyno-komunikatsiyni ta informatychni kompetentnosti yak komponenty systemy profesiyno-spetsializovanykh kompetentnostey vchytelya informatyky" [Informationcommunication and informational competencies as components of the system of vocational-specialized competences of the teacher of informatics], Informatsiyni tekhnolohiyi i zasoby navchannya [Information Technologies and Learning Tools], vol. 13, no. 5, URL: https://journal.iitta.gov.ua/ index.php/itlt/article/view/183/169 (accessed 2, February 2019).

2. Grytsiuk, O. S., Bespartochna, O. I. (2016), "Struktura matematychnoyi pidhotovky studentiv inzhenernykh spetsial'nostey $\mathrm{v}$ aspekti profesiynoyi spryamovanosti navchannya" [Structure of mathematical education of students of engineering specialties in the aspect of professional orientation of training], Pedahohika formuvannya tvorchoyi osobystosti $u$ vyshchiy $i$ zahal'noosvitniy shkolakh [Pedagogy of formation of creative personality in higher and secondary schools], no. 51 (104), pp. 436-443.

3. Mykhalevych, V. M., Tyutyunnyk, O. I. (2013), "Proektuvannya navchal'nykh zadach z liniynoho prohramuvannya $\mathrm{z} \quad$ vykorystannyam system komp'yuternoyi matematyky" [Designing of educational tasks in linear programming with the use of systems of computer mathematics], Informatsiyni tekhnolohiyi $i$ zasoby navchannya [Information Technologies and Learning Tools], vol. 38, no. 6, pp. 123-137.

4. Kobyl'nyk, T. P., Kohut, U. P. (2014), “Systemy komp'yuternoyi matematyky u navchanni studentiv napryamu pidhotovky "Informatyka" [Systems of computer mathematics in the training of students on-line training "Informatics"], Informatsiyni tekhnolohiyi $i$ zasoby navchannya [Information Technologies and Learning Tools], vol. 40, no. 2, pp. 50-64.

5. Parf'onova, N. D., Klochko, T. V. (2009), "Obchyslennya intehraliv vid funktsiy kompleksnoyi zminnoyi za dopo-mohoyu zalyshkiv v systemakh komp'yuternoyi matematyky" [Calculation of integrals from functions of a complex variable with the help of residues in systems of computer mathematics], Informatsiyni tekhnolohiyi $i$ zasoby navchannya [Infor- mation Technologies and Learning Tools], vol. 14, no. 6, URL: https://journal.iitta.gov.ua/index.php/ itlt/article/view/211/197 (accessed 2, February 2019).

6. Kobyl'nyk, T. P. (2011), "Prohramne zabezpechennya spetsial'noho pryznachennya u navchanni studentiv informatychnykh spetsial'nostey pedahohichnoho universytetu" [Software of special purpose in teaching students of in-formal specialties of the pedagogical university], Informatsiyni tekhnolohiyi $i$ zasoby navchannya [Information Technologies and Learning Tools], vol. 23, no. 3. URL: https://journal.iitta.gov.ua/index.php/itlt/article/view/44 0/410 (accessed 5, February 2019).

7. Poyasok, T. B., Bespartochna, O. I. "Orhanizatsiya pedahohichnoyi vzayemodiyi uchasnykiv osvitn'oho protsesu v komp'yuterno oriyentovanomu navchal'nomu seredovyshchi zakladu vyshchoyi osvity" [Organization of pedagogical interaction of participants in the educational process in a computer-oriented educational medium-higher institution of higher education], Informatsiyni tekhnolohiyi $i$ zasoby navchannya [Information Technologies and Learning Tools], vol. 67, no. 5. pp. 199-212.

8. Zhaldak, M. I., Lapins'kyy, V. V., Shut, M. I. (2004), Kompyuterno-oriyentovani zasoby navchannya matematyky, fizyky, informatyky: Posibnyk dlya vchyteliv [Computer-oriented means of teaching mathematics, physics, computer science: A guide for teachers], NPU imeni M.P. Drahomanova, Kyiv, Ukraine.

9. Bykov, V. Yu., Leshchenko, M. P. (2016), "Tsyfrova humanistychna pedahohika: aktual'ni problemy pedahohich-nykh doslidzhen' u haluzi vykorystannya IKT v osviti" [Digital humanistic pedagogy: actual problems of pedagogical research in the field of ICT use in education], Informatsiyni tekhnolohiyi $i$ zasoby navchannya [Information Technologies and Learning Tools], vol. 53, no. 3. pp. 1-17.

10. Morze, N. V., Buynyts'ka, O. P. (2017), "Pidvyshchennya rivnya informatsiyno-komunikatsiynoyi kompetentnosti naukovo-pedahohichnykh pratsivnykiv - klyuchova vymoha yakosti osvitn'oho protsesu" [Increasing the level of information and communication competence of scientific and pedagogical workers is a key requirement of the quality of the educational process], Informatsiyni tekhnolohiyi $i$ 
zasoby navchannya [Information Technologies and Learning Tools], vol. 59, no. 3. pp. 189-200.

11. Zhaldak, M. I. (2003), Komp'yuter na urokakh matematyky: Posibnyk dlya vchyteliv [Computer at the matematics lessons: A Teacher's Guide], Dinit, Kyiv, Ukraine.

12. Kiyanovs'ka, N. M., Rashevs'ka, N. V., Semerikov, S. O. (2014), "Etapy rozvytku teoriyi i metodyky vykorystannya informatsiyno-komunikatsiynykh tekhnolohiy u navchanni vyshchoyi matematyky studentiv inzhenernykh spetsial'nostey u Spoluchenykh Shtatakh Ameryky" [Stages of the development of the theory and methodology of the use of information and communication technologies in the teaching of higher mathematics of engineering engineers in the United States of America], Informatsiyni tekhnolohiyi $i$ zasoby navchannya [Information Technologies and Learning Tools], vol. 43, no. 5. pp. 68-83.

13. Parf'onova, N. D. (2012), "Novi pidkhody do vykorys-tannya vil'no poshyryuvanoyi systemy komp'yuternoyi matematyky Maxima u navchanni funktsiy kompleks-noyi zminnoyi" [New approaches to the use of the freely distributed system of computer mathematics Maxima in the study of functions of a complex variable], Informatsiyni tekhnolohiyi $i$ zasoby navchannya [Information Technologies and Learning Tools], vol. 27, no. 1. URL: https://journal.iitta.gov.ua/index.php/itlt/article/view/62 2/481 (accessed 7, February 2019).

14. Pochtovyuk, S. I. (2009), "MATLAB - matematychna kompyuterna systema dlya naukovodoslidnyts'kykh ta tekhnichnykh rozrakhunkiv" [MATLAB is mathematical computer system for scientific research and technical calculations], Informatsiyni tekhnolohiyi $i$ zasoby navchannya [Information Technologies and Learning Tools], vol. 9, no. 1. URL: https://journal.iitta.gov.ua/index.php/itlt/article/ view/18/10 (accessed 10, February 2019).

15. Sin'ko, Yu. I. (2009), “Systemy komp'yuternoyi matematyky ta yikh rol' u matematychniy osviti" [Systems of computer mathematics and their role in mathematical education], Informatsiyni tekhnolohiyi $v$ osviti [Information technology in education], no. 3. pp. $274-278$.

16. Ertel, W. (2012), Advanced Mathematics for Engineers. University of Applied Sciences RavensburgWeingarten, Weingarten, Deutschland.

17. Barendregt, H., Wiedijk, F. (2005), "The Challenge of Computer Mathematics", Philosophical transactions. Series A, Mathematical, Physical, and Engineering Sciences, no. 363 (1835), pp. 2351-2373.

18. Pokryshen', D. A., Nosenko, Ye. Yu. (2012), "IKT dlya rozv'yazuvannya systemy nerivnostey" [ICT for solving the system of inequalities], Informatsiyni tekhnolohiyi $i$ zasoby navchannya [Information Technologies and Learning Tools], vol. 27, no. 1. URL: https://journal.iitta.gov.ua/index.php/itlt/article/view/61 3/472 (accessed 7, February 2019).

19. Moler, C. B. (2004), Numerical Computing with MATLAB, SIAM, Philadelphia, PA, USA.

20. Otto, S. R., Denier, J. P. (2005), An Introduction to Programming and Numerical Methods in MATLAB, Springer-Verlag London Limited, London, United Kingdom.

21. Abdul Majid, M., Huneiti, Z. A., Balachandran, W., Balarabe Y. (2013), "Matlab as a Teaching and Learning Tool for Mathematics: A Literature Review", International Journal of Arts \& Sciences, no. 6 (3), pp. 23-44.

22. Shapovalenko, V. A., Bukata, L. M., Trofymenko, O. H. (2011), Chysel'ni metody modelyuvannya ob'yektiv: Chastyna 2: Metod. vkazivky dlya lab. ta prakt. zanyat'. Modul' 2 [Numerical Methods of Modeling Objects: Part 2: Methodical instructions for the laboratory and practice lessons. Module 2], VTS ONAZ, Odesa, Ukraine.

Стаття надійшла 13.05.2019. 